\title{
Urban Violence
}

\section{David Herbert, Swansea}

\section{Introduction}

Crimes of violence cover a range of acts committed by a perpetrator or perpetrators against victims. They almost invariably have a traumatic impact upon the victims and excite a great deal of interest from the media. Homicide as the most unambiguous form of violent crime ranks at the very top of police priorities for investigation and receives the heaviest sanctions from the criminal justice system. Unsolved homicides or murders remain a blight on the police record and files are rarely closed. In recent years, advances in forensic science, particularly in relation to DNA profiling, have allowed old cases to be re-opened and prosecutions brought about many years after the actual crime was committed. Successful strategies to reduce violent crime, such as those in New York City that are linked with «zero tolerance», are widely used as examples of good practice and sound policy. Governments are highly sensitive to changing levels of crime trends and those related to crimes of violence are the most sensitive of all. The study of crime has always been hindered by a lack of confidence in the completeness and accuracy of the criminal record. Many crimes go unrecorded or even unreported and there is a "dark area» of such crimes that is of the order of $80 \%$ (HERBERT 1982). Some categories of violent crimes are less vulnerable to these caveats and homicide is clearly one of these. If someone is the victim of a homicide then mostly there is the physical evidence of the body. Even in the rare cases where that physical evidence is not present, individuals will be missed as they are part of networks of family, friends and acquaintances that will eventually seek them out. There are several types of even violent crimes however where there will be a dark area of unreported offences. Domestic violence is one such area, common assault may be another and sexual offences, including rape, often do not lead to a victim informing the police. As with all types of crime, we are dealing with a difficult and sometimes slippery phenomenon both as a concept and as an evidence based set of incidents. Finally, by way of introduction, the focus on urban violence can be justified in both conceptual and empirical terms. Firstly, it will be argued that city environments can engender violent situations, and secondly, the vast majority of acts of violence occur in cities. Of course, there is rural violence and its impacts can be equally devastating but in terms of scale and the existence of an urban effect, it is a problem associated with the environments of the city.
This paper will focus initially on current empirical trends and the evidence upon which the monitoring of urban violence is based. It will then review in broad terms some of the attempts to understand the phenomenon of urban violence. In particular, there is some discussion of the possible "geographies» of urban violence and the ways in which concepts such as place, space and territory can contribute to our overall understanding (see also Racine 2002).

\section{Trends in urban violence in the United Kingdom}

There is a widely held belief that crimes of violence have increased in the past several decades. Given the problematic nature of recorded crime data, it is difficult to make general statements that confirm or deny this belief. VAN DIJK (1999) used a United Nations Crime and Justice survey, based on sample surveys of the population at large, to show that the homicide rate in developed countries in 1994 was much higher than it had been in 1974 but that the reverse tended to be true of developing countries. This survey has the merit of not relying on police records though some of the difficulties of making comparisons remain. To examine trends in more detail the experience of the United Kingdom and urban violence offers one set of indicators.

When Susan Smith (1989: 271) wrote that the streets of Britain were getting meaner, she was perhaps being more prophetic than she had intended. Her comment was largely based on a historical view of crime rates that showed an increase of recorded crime of $60 \%$ over the period 1975 to1985. SMITH also rested her case on the evidence becoming available from national crime surveys derived from the experience of victims irrespective of whether this experience had been reported to the police. These surveys could be expected to be fuller accounts of crime than the police record. Crimes had increased, the areas that suffered most were those typified anyway by deprivation and disadvantage to which victimisation added an additional dimension. The streets were not only meaner but also less safe for physical well-being and neither home nor workplace seemed to offer a total solution as safe havens. The police record for homicide in the period from 1967 to 2002 showed an increase from 354 per year to one of 832 (Flood-Page \& TAYlor 2003). As rates per one million people, these represent an increase from 7.3 to 16.0. The dark area for homicide was small and there were less than $5 \%$ of incidents where no suspect was brought to court in the period 1991 to 2001. Over 
this period, around three-quarters of those indicted were found guilty in the courts and just over $20 \%$ were acquitted. In 2001, two-thirds of victims were males compared with $50 \%$ in 1991 and one-third was killed with a sharp instrument. People they would have known killed $72 \%$ of female victims and partners or former partners were responsible for $46 \%$ of the offences (MATTINSON 2001). Strangers were the main suspects in only $16 \%$ of female homicides but this rose to $37 \%$ for males. Emotional stimuli such as temper, revenge and quarrels accounted for $40 \%$ of the reasons for homicides and this was the largest single category. Other situations involved robberies or burglaries were apparently motiveless, or involved mentally disturbed offenders. Statistically, the two groups at greatest risk were children under the age of one year and youths aged 16 to 29. The British Crime Survey (FLOOD-PAGE \& TAYLOR 2003) calculated the risk of being the victim of violent crime as $4 \%$ for the population at large but $16 \%$ for those aged 16 to 24 . This survey classified four types of violent crime as domestic (22\%), mugging (15\%), stranger (32\%), and acquaintance $(31 \%)$. Two-thirds of the incidents took place at night, the home was the most common location $(27 \%) ; 80 \%$ of offenders were male and over half the victims knew the assailant.

There are several trends related to urban violence that are attracting a great deal of interest in the United Kingdom. One such trend is the evidence for urban disorder or urban incivilities (HERBERT 1993), which may act as an indicator of the onset of more serious crime. The idea of urban disorder originated with the «broken window» hypothesis (WILSON \& KELLING 1982) and has been developed in relation to a range of concepts such as neighbourhood change or community life cycles. Disorders can be a range of things such as minor acts of vandalism and graffiti but their incidence, particularly where no remedies are sought, is often the precursor of urban violence. In the British Crime Survey, one third of respondents said that disorders had a negative effect on their lives and low income residential areas were the foci of such disorders. A second and perhaps related trend is that which links drugs to violent crime. AINSWORTh (2002) suggested that extraordinary levels of violence were hitting some of Britain's poorest communities as the use of crack cocaine spiralled. Commander ALAN Brown of the UK's Operation Trident identified a growing culture among young people to carry guns and sell drugs in ways that demand power and respect in their eyes (AINSWORTH 2002). Experience in the United States is similar and the Uniform Crime Reports recorded 87,900 arrests for heroin cocaine in 1982 but 529,200 in 2000. The third and again related trend is that of an increase in the possession and use of firearms. Gun murders remain small numerically in the United
Kingdom but have increased significantly. Factors are thought to be the increase in gang activities, the lucrative market in consumer items such as mobile phones and the diversion of police to anti-terrorist duties.

\section{Global trends}

The United Nations supported Global Report on Crime and Justice (Newman 1999) allows us to view some of these trends in a comparative framework. The Global Report is correctly concerned with the need for caution in making international comparisons. There are differences in recording practices and also in crime definitions. The dark area of unreported or unrecorded crime remains a problem and the official records may be unrepresentative. White-collar crimes such as tax evasion and fraud are less easily detected than burglaries. Attitudes towards violence vary considerably and acts deemed to be acceptable in some societies are regarded as criminal in others. There are also different interpretations within societies. The United Kingdom offers a graphic example in the debate over domestic violence. A Government survey suggested that one in four women had been victims of domestic violence but critics of the report argued that $80 \%$ of the incidents should be regarded as trivial (HoLbrooK 2003). In many ways crime including violent crime is socially defined and is often more a comment of the values of those who administer the criminal justice system than of society as a whole. The gulf between the rule-makers and the rule-breakers is very wide.

The Global Report did not rely entirely on official statistics and employed an International Crime and Justice Survey to support its analyses (VAN DIJK 1999). National crime surveys of this kind, that sample the victimisation experience of residents over a specified period of time are now widely adopted in developed countries. This type of survey has thrown a great deal of light on, for example, the reality of the "dark area" and the ways in which it varies from one type of crime to another. In many ways the victimisation surveys have provided some higher level of confidence in the official statistics as the relative positions if not the actual volumes of crime are broadly confirmed. There is also much greater understanding of the real problems of fear of crime and the effects that these have on people's everyday lives. The International Crime and Justice Survey investigated the different cultural values attached to acts of violence in different societies and found that over 17 acts of violence the correlation coefficient was greater than 0.9 , which showed a very high level of consensus on what kinds of violence constituted a crime. Of the top four offences, globally regarded as serious, three were defined as violent crimes. 


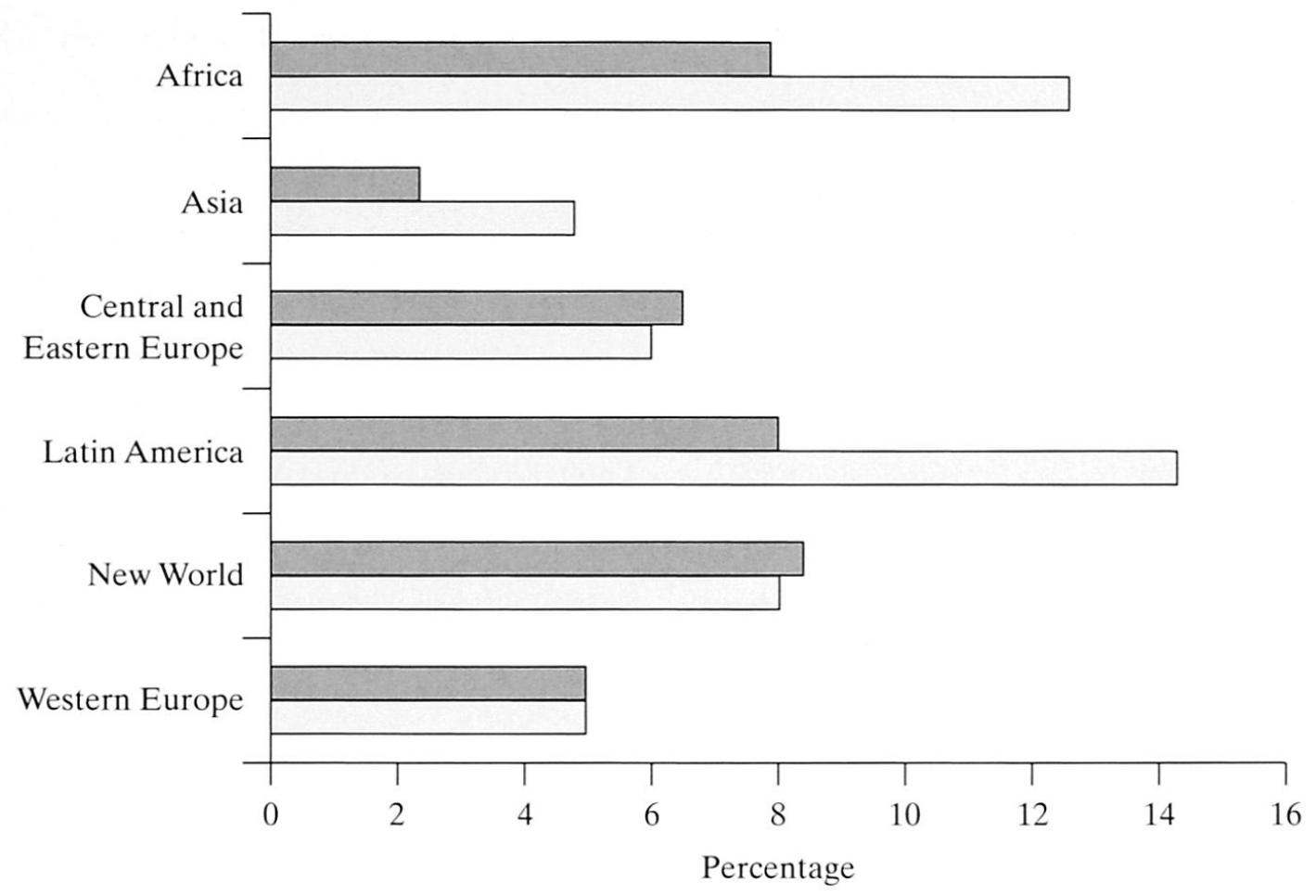

Violence (males)

Violence (females)

Fig. 1: Percentage of men and women victimised by violent crime in urban areas of six global regions, 1989 to 1996.

Geschlechterspezifische Anteile der Opfer von Gewaltverbrechen in urbanen Räumen von sechs globalen Regionen, 1989 bis 1996.

Taux d'hommes et de femmes victimes de crimes dans les aires urbaines de six régions du monde, de 1989 à 1996. Source: VAN DIJK 1999

VAN DiJK (1999), who completed the main analysis of the International Crime and Justice Survey, argued that the experience of being criminally victimised had become a statistically normal feature of urban life all over the world, though the type of victim experience varied. Africa and Latin America now have the highest rates of violent crime, though the United States, with twenty times the violent crime rate of Japan, was the most violent developed society (Figure 1). Within industrial societies, there was some indication that the gaps were narrowing; victimisation by violence remained stable in the United States between 1988 and 1995 but increased in Europe. VAN DIJK (1999) used the information to develop an investigation into the correlates of violent crimes. His subset of «contact crimes» comprised robbery, sexual assault and common assault and the key correlates of these were economic strain (feelings of deprivation), gun ownership, lower education, and life style (defined as going out in the evenings). Taken together and used with a standard multivariate analysis, these four fac- tors accounted for $68 \%$ of the overall variance in rates of contact crimes by country. The life style factor was contentious in some ways as it was constructed as part of an affluence measure. The particular definition, going out in the evenings, had more logic as it meant placing people at risk outside the home.

Violence against women was most prevalent in Latin America, Sub-Saharan Africa and a region defined as the New World (United States, Canada, Australia and New Zealand). From the 62 countries reporting homicide rates for 1994, the range was from less than 5 to over 800 per million populations. Arab States and Western Europe had the lowest rates with highest rates in Latin America and Sub-Saharan Africa. Official records suggest that city dwellers have a higher risk of being victims of violence (Figure 2). In general, countries with high levels of gun ownership also have high levels of gun related crimes. Illicit drug related offences have increased most dramatically in the past two decades. Organised crime groups such as 


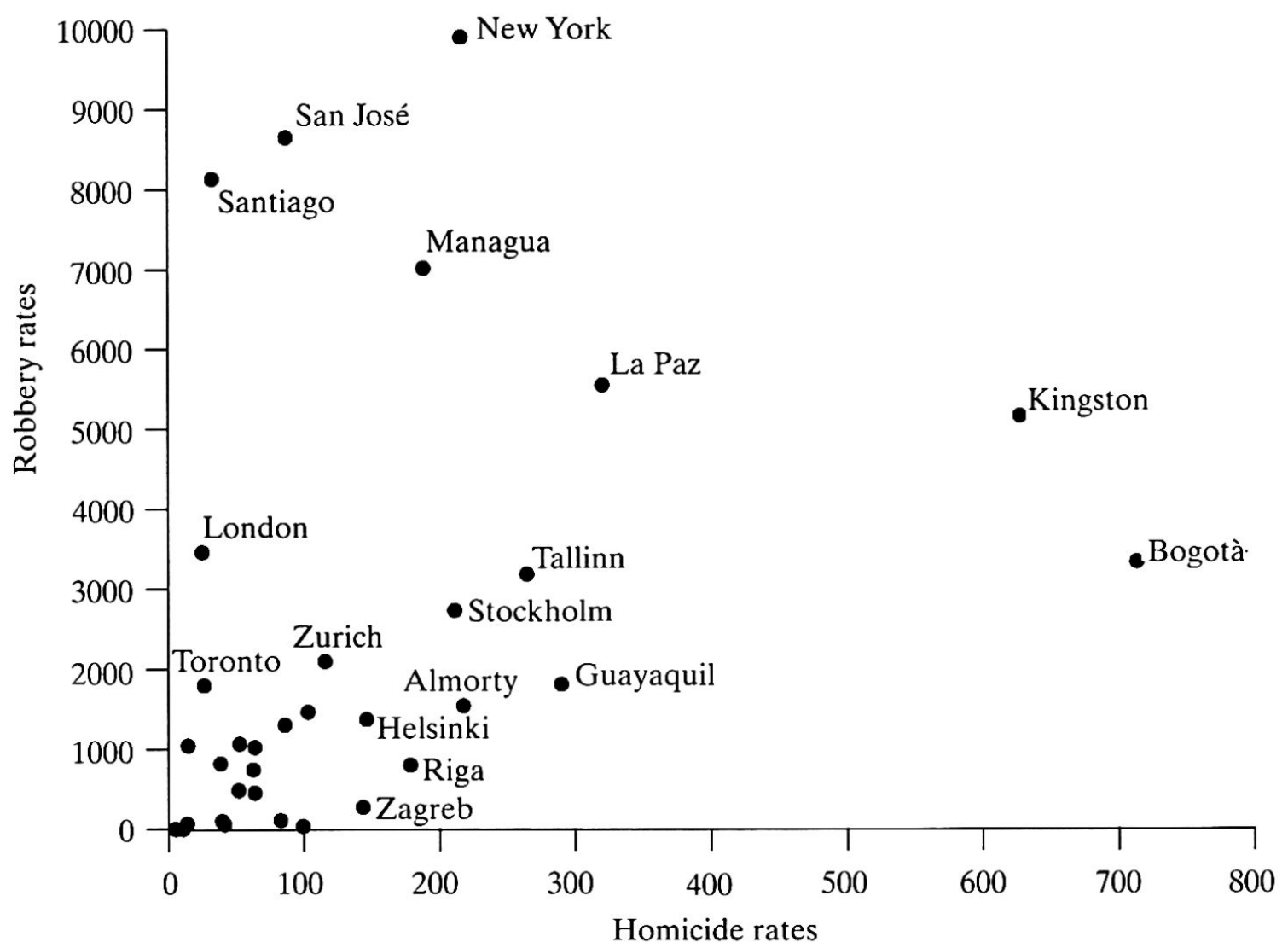

Fig. 2: Homicide and robbery rates for 35 cities, 1994

Totschlags- und Diebstahlraten in 35 Städten, 1994

Taux d'assassinats et de vols dans 35 villes, 1994

Source: Fifth United Nations Crime and Justice Survey (Newman 1999)

the Columbian cartels, Chinese Triads, Mafia, Jamaican posses and Russian gangs resort to violence wherever it is needed to protect their business.

\section{The underpinnings of urban violence}

The debate on the forces behind the perceived rise in urban violence has grown with increased concern about what appear to be global trends. The issues of definition assume importance and in particular there is a debate about new forms of violence and their relevance to the global trend. As Levi \& Maguire (2002) have argued, violent crime appears to be a self-evident category yet the dispute about what should be included is very much ongoing. They cite as contested categories, injuries that are outcomes of corporate negligence, road accidents, «justifiable» use of force by authorities and the rise of terrorism. Some of these contested categories are among the most rapidly increasing types of violence. Ayres \& Haywood (2001) reported 3409 people killed and 38,155 seriously injured on British roads in the year 2000 and in the same year there were 96,300 prosecutions for driving under the influence of alcohol. The Health and Safety Executive (HSE) (2001) in the United Kingdom reported 736 deaths and 47,373 major injuries connected with workplace in 2000. There are many other examples that could be added to show that the extent of urban violence is much greater than that recorded in official statistics as homicide and other forms of physical assaults.

Despite the contested categories, research by the International Crime and Justice Survey (Newman 1999) has shown a high level of consensus on 17 more common categories of violent crime. Yet there are cultural and temporal variations. The older sub-cultural theories (Wolfgang \& FerRacuti 1967) argued that within specified groups some forms of criminality were regarded as acceptable or at least unexceptional forms of behaviour. The early studies referenced, for example, Italian communities in American cities in the 1920s and 1930s but more recent examples include Northern Ireland where both sets of protagonists sought 
to establish «legitimate» targets for violence. Terrorist groups such as $\mathrm{Al}$ Qa'ida are prepared to justify as acceptable extreme acts of urban violence and argue that their opponents behave in comparable ways. The end game in this line of argument is the act of war where violence is by definition the means by which the end is achieved. This line of argument, however, takes us well beyond the limits of normal definitions of violent crime and is pursued no further here. The main forms of violent crime are homicides and the range of offences that involve physical injuries to victims as a result of actions by their perpetrators. It is these forms of violence that put ordinary people at risk and raises fears of urban safety to high levels. A broad interpretation of the findings of the British National Crime Surveys is that each year 1 in 25 adults are likely to fall victims to violent crime but hidden in this statistic are the facts of repeat victimisation on particular types of people and the life style characteristics that place them most at risk.

Attempts to explain violence are diverse and general statements or theories are rarely convincing. They are consistently undermined by the apparent exceptions, often in a majority of people who fit the criteria but do not apparently commit violent crime. LEVI \& MAGUIRE (2002) helpfully review the broad types of theories of explanation and identify the classical distinction in the psychological literature between instrumental and expressive violence. The former covers activities that employ violence as part of the means of achieving economic gain; the latter refers to violence that is emotionally satisfying but has no economic gain. The former might, for example, include turf wars between gangs of drug dealers, the latter crimes of passion and domestic violence. Levi \& Maguire (2002) define three broad sets of theories as:

- Biology and social biology, which concentrates on the physiology of the brain and the ways in which it might lead to loss of control (MoIr \& JeSSELL 1995).

- Psycho-analytical and clinical approaches that seek evidence of abnormality about known offenders from either their physical/mental make up or their background (DoBASH et al. 2001). Caveats within this set of concepts include the partialness of the evidence, some offenders come from dysfunctional backgrounds but many do not, and the time factor has to be considered, as offenders appear normal for much of their lives. Gresswell \& Hollin (1994) categorised a set of known serial killers as either visionary, missionary, lust-motivated, or power driven.

- Socio-cultural and social psychological theories cover a broad canvas. The «interactionists» focus on the relationship between the cognitive sets of the assailants and the behaviour of the victims. Again, sub-cultural and temporal variation approaches are widely used and SMrTH (2002), writing more widely on crime asserted that offending is most commonly committed by young people and is therefore closely linked to the life course.

These broad schools of thought contain strong bases for the explanation of many forms of urban violence and can be fitted to a range of situations. They are not necessarily exclusive or contradictory and the most general lesson for those attempting to explain criminal behaviour is that a good package of working theories which can be drawn upon in selective and responsible manner offers the best way forward.

\section{Spatiality and urban violence}

As there are temporal variations in the incidence of crime and offending, so there are spatial variations. In other words there is strong evidence that there are geographies of crime, including violent crimes. There are questions that relate to whether geography has any independent status in the understanding of crime or whether it is an intervening or dependent variable. The answers are not clear-cut but there is sufficient evidence now to propose that geography matters and that the spatial dimension cannot be ignored. In its guises as environmental criminology (BRANTINGHAM \& BRANTINGHAM 1981), situational crime analysis (CLARKE 1995) and crime pattern analysis, the roles of geography are widely accepted and used by criminologists. Geographical Information Systems are essential parts of both criminological research and the practical workings of many police authorities. The technologies of spatial analysis can be used both to tease out the patterns of crime and to reveal the complex relationships between offenders, offences, victims, and environments of the city (Hirschfield \& Bowers 2001). Crime profiling often contains a strong consideration of place and space and has allowed detailed and telling interpretations of specific criminal events (CANTER 2003). Botroms \& WILES (2002: 620) define environmental criminology as:

«The study of crime, criminality and victimisation as they relate, first, to particular places and, secondly, to the way in which individuals and organizations shape their activities spatially, and in so doing are in turn influenced by placebased or spatial factors.»

The general principle associated with environmental criminology can be applied effectively to crimes of violence in the city. At the level of the simple mapping of crimes of violence to reveal patterns, there are strong clusters of offences in particular and repetitive parts of cities. The term "geographies" of urban violence is used advisedly as different types of crime have different geographies; the cluster is not consistently 
in the same place. Many violent crimes that include robberies, common assault and affray, typically cluster around parts of the inner city and places of entertainment such as bars, discos or clubs. The common feature of these places is that they are areas of conflux where people are drawn together. There is therefore the particularly urban phenomenon of a crowd or dense gathering of people at one type of place; the conflux itself and the features of the environment in which it occurs contributes to the likelihood of violence. Many assaults and affrays revolve around the related qualities of the social behaviour patterns in these places. The clientele is usually young, individuals and groups seeking entertainment with alcohol and increasingly drugs as part of that entertainment. These are place-defined situations in which violence can and does occur. Robberies are also frequent in the same kinds of locations. The same set of criteria of conflux and less responsible behaviour may apply but here the crowd provides a target population upon which offenders may prey. Matrinson (2001) showed that around a quarter of all incidents of stranger violence in the United Kingdom occurred in clubs or pubs on weekend evenings. Over two-thirds of stranger violence was thought by the victims to have been perpetrated by people under the influence of either alcohol or drugs. The geography of these forms of urban violence, which could be extended to include some sexual assaults and homicides, reflects the opportunity structures of the urban environment. It is the coming together of a set of significant conditions that produces the potential for violence but the place itself has a role to play. A key factor in the control of such areas is of course the role of the police. The police in any city will know the areas where this kind of gratuitous violence is most likely to occur and will respond accordingly with additional policing and increasingly the strategic deployment of closed circuit television cameras and other crime prevention techniques.

This set of crimes of violence has a distinctive geography. The focus in this discussion has been upon the inner city but the same principles apply to other concentrations of bars and places of entertainment where the same conditions prevail. Other forms of urban violence however have quite different geographies. There are crimes of violence in which women or elderly people are much more likely to be victims. For women this covers the range of sexual assaults; for both women and the elderly, muggings and bag-snatchings are crimes where they are particularly at risk. There are environments where these risks are greatest such as shopping centres (THOMAS \& Bromley 1996) and, for sexual assaults in particular, parks and secluded places. Women and the elderly tend to suffer most from fear of crime. They will seek to avoid certain parts of the city and to avoid being away from home during hours of darkness. Again, for criminals, the opportunity structures of the city will lead them to specific types of victims, whether it is a female jogger in a park or an elderly person homeward bound with shopping.

Domestic violence normally occurs in the home and clearly has a very different kind of geography. Here the «dark area» may be large and contested. A study of homicide in the United Kingdom (FLOOD-PAGE \& TAYLOR 2003) showed that $72 \%$ of female victims knew the main or only suspect at the time of the offence; partners, ex-partners or lovers killed nearly half of female victims. Men were more likely to be killed by a stranger and this was the case in $37 \%$ of male homicides. There is now a great deal of accumulated evidence to show that for all kinds of the most common crimes and also for many crimes of violence, some types of residential areas and parts of these areas hold a disproportionate share of offences and victims. Almost invariably these are deprived residential areas where the incidence of crime is added to the wider experience of disadvantage and poverty. Some of the classic British studies of specific problem estates and inner city districts show how disadvantage, disorder, crime and violence have become standard ingredients of life. The advent of drugs and changing attitudes towards violence has served to accentuate the problems. Damer's (1974) early depiction of what he termed a «dreadful enclosure» in Glasgow provides one such case study; BARKE \& TuRnBUlL's (1992) study of Meadowell is another. In the United States, WILSON (1987) located the urban underclass in the inner parts of American cities and Davis (1990) drew a graphic picture of the criminalized «places of terror» and compared these with the fortified affluent cells of the urban rich. For Stockholm, WıкSTRÖm's (1991) maps of violence in public places show a pattern that is highly concentrated in the central city whereas domestic violence is far more dispersed across the city with concentrations in poorer public housing areas (Figure 3 ). Where territorial concentrations of urban violence occur, concepts such as place, territory and community present themselves as key components of a preventive or ameliorative strategy. RACINE (2002) developed this approach with his attention to territories of gratification, respect and recognition. Community action is notoriously difficult to initiate and sustain but its potential is considerable. As a footnote to this discussion, it is worth recording the evidence for regional concentrations of violence. GUERRY (1833) many years ago in France identified the "violent south» as the locus for violence that he linked to hot climates; HARRIES \& BRUNN (1978) used the same phrase to describe the southern states of the United States though their culture of violence theory included attitudes towards gun ownership and race. 


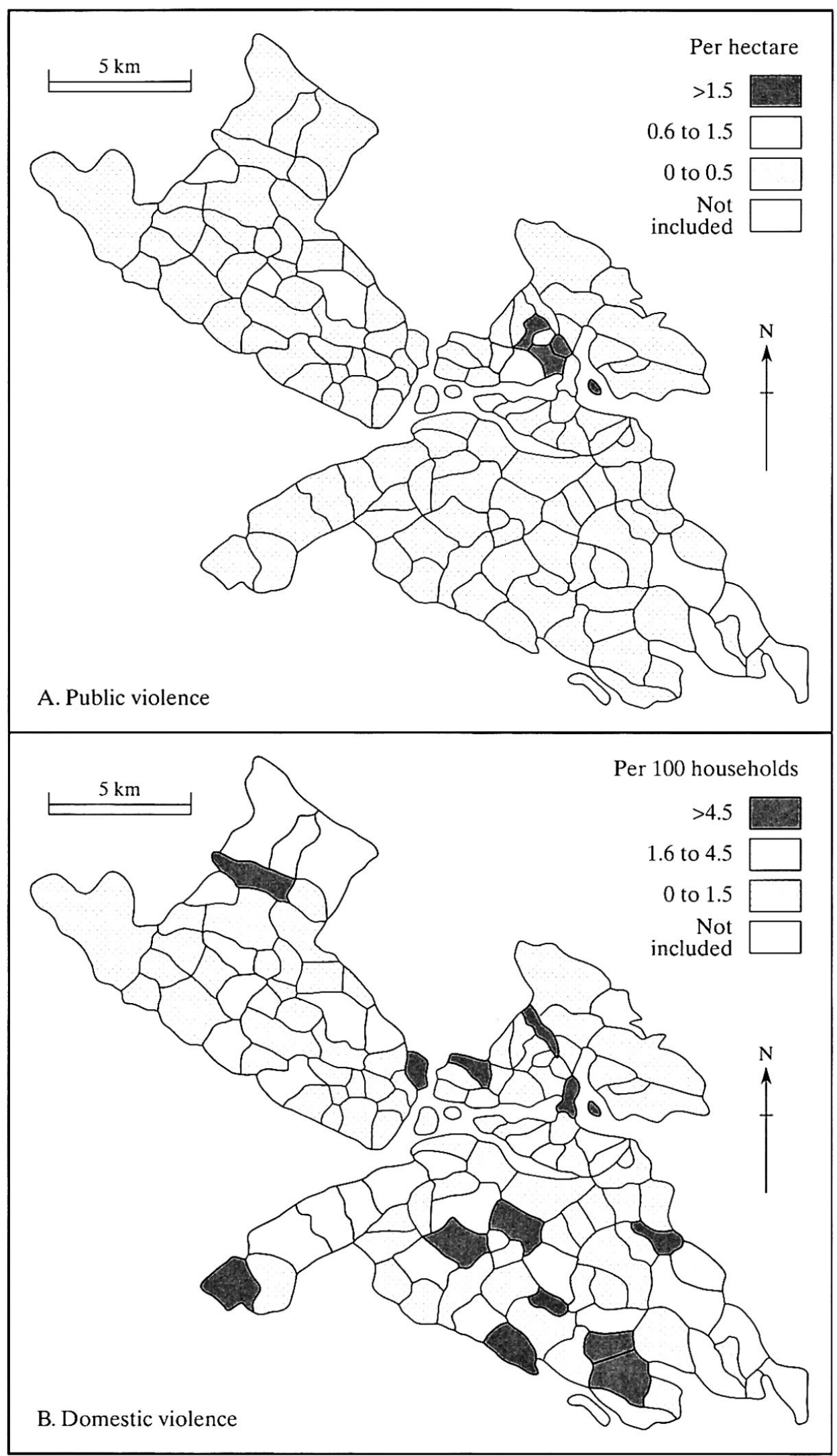

Fig. 3: Two geographies of violent crime from Stockholm (1982)

Die geographische Verteilung von Gewaltverbrechen in Stockholm (1982)

Deux géographies de crimes à Stockholm (1982)

Source: WIKSTRÖM 1991 


\section{Conclusions}

There is a widely held consensus that violence is an endemic part of the city on a global scale. There is also an understanding that the expressions of urban violence will vary from one part of the world to another and a belief that problems of urban violence are getting worse. Given the caveats associated with data and the facts of cultural interpretations, it is unlikely that anything approaching perfect clarity on these positions and trends will be achieved but there are grounds for believing that they are well founded. There are new dimensions to urban violence, partly related to the continuing process of globalisation and its repercussions. Drug dealing is now an international trade that touches upon very many cities in many parts of the world. Organized crime syndicates, often related to the drug trade have global and far-reaching dimensions. The trail from production areas through to distribution networks and local suppliers and users, engenders the prospect of violence at every point along the way. Guns and firearms seem to have become part of the culture of this trade and have spilled over into other forms of violent crime. Although terrorism has not been considered as part of this brief, it has some role in creating a culture of urban violence and of spawning related criminal activities.

We cannot afford to accept violence in a passive way. There is nothing inevitable about its rise in our cities and many actions are taken to control and reduce its impact. The police stand in the front line of the strategy against urban violence and the most important determinant of whether a case will be solved is the information supplied by victims or witnesses to the police (MAguire \& Norris 1992). Bowling \& Foster (2002) note that clear up rates for homicide in the United Kingdom is now $90 \%$ and for violence against persons it is $62 \%$. The current situation of urban terrorism prejudices this process by drawing large numbers of police and other resources away from the business of «conventional» crime. Beyond policing and special task forces, there are roles for community action and for wider policies that address the roots of economic disadvantage.

\section{References}

Ainsworth, R. (2002): Crack Trade Violence Hits UK's Poorest. - BBC News on www.cannabisnews.com, June $24^{\text {th }}$.

Ayres, M. \& P. Hayward (2001): Motoring Offences and Breath Test Statistics. - Home Office Statistical Bulletin, London: Home Office.

Barke, M. \& G. Turnbull (1992): Meadowell: The Biography of an «Estate with Problems». - Aldershot: Avebury.
Botтoms, A.E. \& P. Wiles (2002): Environmental Criminology. - In: Maguire, M., Morgan, R. \& R. Steiner (eds): The Oxford Handbook on Criminology. $-3^{\text {rd }}$ Edition, Oxford: Oxford University Press: 620-656.

Bowling, B. \& J. Foster (2002): Policing and the Police. - In: Maguire, M., Morgan, R. \& R. Steiner (eds): The Oxford Handbook on Criminology. $-3^{\text {rd }}$ Edition, Oxford: Oxford University Press: 980-1033.

Brantingham, P.J. \& P.L. Brantingham (1981): Environmental Criminology. - Beverly Hills, California: Sage Publications.

CANTER, D. (2003): Mapping Murder: The Secrets of Geographical Profiling. - London: Virgin Books.

Clarke, R.V.G. (1995): Situational Crime Prevention. - In: Tonry, M. \& D. Farrington (eds): Building a Safer Society. - Chicago: University of Chicago Press: 91-150.

DAMER, S. (1974): Wine alley: the sociology of a dreadful enclosure. - In: Sociological Review 22: 221-248.

Davis, M. (1990): City of Quartz: Excavating a Future for Los Angeles. - London: Verso.

Dobash, R.E., Dobash, R.D., Cavanagh, K. \& R. Lewis (2001): Homicide in Britain. - Research Bulletin 1, University of Manchester.

Flood-PAGe, C. \& J. TAYlor (2003): Crime in England and Wales 2001/2002: Supplementary Volume. - London: Home Office.

Gresswell, D. \& C. Hollin (1994): Multiple murder: a review. - In: British Journal of Criminology 34: 1-29. Guerry, A.M. (1833): Essai sur la Statistique Morale de la France avec Cartes. - Paris: Crochard.

Harries, K.D. \& S.J. BrunN (1978): The Geography of Laws and Justice. - New York: Praeger.

Health and Safety Executive (HSE) (2001): Statistics, 2000-2001. - London: Health and Safety Executive.

Herbert, D.T. (1982): The Geography of Urban Crime. - London: Longman.

Herbert, D.T. (1993): Neighbourhood incivilities and the study of crime in place. - In: Are 25: 45-54.

Hirschfield, A. \& K. Bowers (eds) (2001): Mapping and Analysing Crime Data: Lessons from Research and Practice. - London: Taylor and Francis.

Holввоок, J. (2003): The Law and the "One in Four». - Spiked-Online, July $23^{r d}$.

Levi, M. \& M. Maguire (2002): Violent Crime. In: Maguire, M., Morgan, R. \& R. Steiner (eds): The Oxford Handbook on Criminology. $-3^{\text {rd }}$ Edition, Oxford: Oxford University Press: 795-843.

Maguire, M. \& C. Norris (1992): The Conduct and Supervision of Criminal Investigations. - London: Her Majesty's Stationery Office (HMSO).

Mattinson, J. (2001): Stranger and Acquaintance Violence: Practice Messages from the British Crime Survey. - Briefing Note 7/01, London: Home Office. Moir, A. \& D. Jessel (1995): A Mind to Crime: the Controversial Links between the Mind and Criminal Behaviour. - London: Michael Joseph. 
Newman, G. (ed.) (1999): Global Report on Crime and Justice. - United Nations Office for Drug Control and Crime Prevention: Centre for International Crime Prevention, New York: Oxford University Press.

RACINE, J.-B. (2002): Explaining, Regulating or Monitoring Violence in the Cities of Tomorrow: Appraisals from French and Swiss Experience. - In: Davies, W.K.D. \& I.J. Townshend (eds): Monitoring Cities: International Perspectives. - Lethbridge, Canada: International Geographical Union Urban Commission: 557-597.

Smith, D.J. (2002): Crime and the Life Course. In: Maguire, M., Morgan, R. \& R. Steiner (eds): The Oxford Handbook on Criminology. $-3^{\text {rd }}$ Edition, Oxford: Oxford University Press: 702-745.

SMITH, S.J. (1989): The Challenge of Urban Crime. In: Herbert, D.T. \& D.M SMITH (eds): Social Problems and the City: New Perspectives. - Oxford: Oxford University Press: 271-288.

Thomas, C.J. \& R.D.F. Bromley (1996): Safety and shopping: Peripherality and shopper anxiety in the city centre. - Environment and Planning C, Government and Policy 14: 469-488.

VAN DIJK, J.J.M. (1999): The Experience of Crime and Justice. - In: Newman, G. (ed.) (1999): Global Report on Crime and Justice. - United Nations Office for Drug Control and Crime Prevention: Centre for International Crime Prevention, New York: Oxford University Press: 25-42.

WIKSTRÖM, P.-O.H. (1991): Urban Crime, Criminals and Victims: the Swedish Experience in an Anglo-American Comparative Perspective. - New York: SpringerVerlag.

Wilson, J.Q. \& G. Kelling (1982): Broken windows. In: The Atlantic Monthly, (March): 29-38.

Wilson, W.J. (1987): The Truly Disadvantaged. - Chicago: University of Chicago Press.

WolfGanG, M. \& F. Ferracuti (1967): The Subculture of Violence. - London: Tavistock.

\footnotetext{
Abstract: Urban Violence

Urban violence has become an endemic feature of cities in all parts of the world. The consensus is that levels of violence are increasing generally but that there are significant differences between different parts of the world. Recent studies review these assumptions and examine the problems associated with monitoring the incidence of violent crime. There are new dimensions to urban violence that include the rise in the drug trade, more organized crime and the trend towards more use of firearms. Cities offer specific situations in which violent crime is more likely to occur. There are geographies of violent crime that not only point out differences between cities but also highlight local concentrations of crime within individual cities. Society seeks to control violent crime, principally through its
}

criminal justice systems but also by involving community action and local initiatives.

\section{Zusammenfassung: Städtische Gewalt}

Städtische Gewalt ist ein weltweites Phänomen. Die übereinstimmende Ansicht ist, dass der Grad der Gewalt im allgemeinen ansteigt, doch herrschen markante Unterschiede in den verschiedenen Teilen der Welt. Kürzliche Studien prüfen diese Vermutungen und untersuchen die Probleme, die sich bei der Beobachtung des Vorkommens von Gewaltverbrechen zeigen. Es gibt neue Dimensionen städtischer Gewalt, die die Zunahme des Drogenhandels beinhalten, das stärker organisierte Verbrechen und den Trend zu häufigerem Gebrauch von Feuerwaffen. Städte schaffen spezifische Situationen, in denen Gewaltverbrechen schneller auftreten. Es gibt geographische Beschreibungen von Gewaltverbrechen, die nicht nur die Unterschiede zwischen Städten aufzeigen, sondern auch die lokalen Konzentrationen innerhalb individueller Städte. Die Gesellschaft versucht, Gewaltverbrechen zu kontrollieren, hauptsächlich durch ihr Kriminal-Justizsystem, jedoch auch durch das Einbinden von gemeinschaftlichem Handeln und von lokalen Initiativen.

\section{Résumé: Violence urbaine}

La violence urbaine est un phénomène mondial. Il y a consensus général sur le fait que le degré de violence augmente dans l'ensemble, quoiqu'il existe des différences notoires dans les diverses parties du globe. Des études récentes ont analysé le degré de véracité de ces suppositions et examiné les problèmes posés par l'observation de l'apparition des crimes. Il existe de nouvelles dimensions de la violence urbaine, qui intègrent l'accroissement du trafic de drogues, l'organisation renforcée de la criminalité et la tendance au recours plus fréquent aux armes à feu. Les villes suscitent des situations spécifiques qui induisent plus rapidement des crimes. Il existe des descriptions géographiques de crimes, qui ne révèlent pas seulement des différences entre villes, mais aussi des concentrations locales à l'intérieur des villes prises individuellement. La société tente de contrôler les crimes, notamment par son système de juridiction criminelle, mais aussi par le recours à une action collective et à des initiatives locales.

\section{Teaching of Geography - relevant questions}

- What reasons are given for the marked difference in urban violence between different regions of the world?

- Why should the incidence of urban violence and the chances of being victimized be much higher in specific districts or neighbourhoods within major cities?

- What changes within Western societies may lead to an increase in the levels of urban violence? 
- List key policy strategies of cities that appear to be most successful in containing and ameliorating the impacts of urban violence.

- Which theories aim to explain the causes of criminality?

- What importance can be attributed to a geographically based approach of observation in connection with criminality?

- Which types of crimes are committed in what kinds of environment?

- Describe the role that local communities can play in contributing towards the understanding and reduction of urban violence.

- One of the problems of studies of crime research is the fact that many offences go undetected. How relevant is this general problem for urban violence research?

- Is a general theory of urban violence viable? To what degree do cultural, spatial and temporal factors influence the general theory?

Prof. Dr. David Herbert, Department of Geography, University of Wales Swansea, Singleton Park, Swansea SA2 8PP, United Kingdom.

e-mail: D.T.Herbert@Swansea.ac.uk

Manuskripteingang/received/manuscrit entré le 23.1.2004

Annahme zum Druck/accepted for publication/accepté pour l'impression: 20.8 .2004 